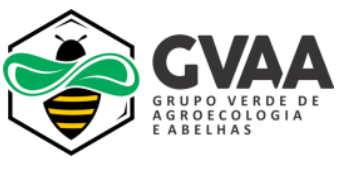

\title{
Baccharis trimera (Less.) DC responses to water restriction
}

\section{Respostas de Baccharis trimera (Less.) a restrição de água}

\author{
Francine Falcão de Macedo Nava ${ }^{(1)}{ }^{1}$, Vilson Conrado da Luz (D) 2 , Lucas Antonio Stempkowski ${ }^{\left({ }^{3}\right.}$, \\ Lenir Fátima Gotz (D) ${ }^{4}$, Fabiana Tonial ${ }^{\text {D } 5}$, Denise Cargnelutti ${ }^{(D)} 6$
}

${ }^{1}$ Engenheira Agrônoma, Doutoranda em Agronomia, Universidade de Passo Fundo, Passo Fundo, francinefmnava@gmail.com; ${ }^{2}$ Engenheiro Ambiental e Sanitarista, Mestrando em Engenharia Química, Universidade de São Paulo, São Paulo, vilson.conradoluz@gmail.com; ${ }^{3}$ Engenheiro Agrônomo, Doutorando em Fitopatologia, Universidade Federal de Viçosa, Viçosa, lucas.stempkowski@ufv.br; ${ }^{4}$ Engenheira Agrônoma, Doutoranda em Solos e Nutrição de Plantas, Universidade de São Paulo, Piracicaba, lenir_gotz@hotmail.com; ${ }^{5}$ Farmacêutica-Bioquímica, Doutora em Microbiologia, Parasitologia e Patologia, Professora, Universidade de Passo Fundo, Passo Fundo, fabianatonial@upf.br; ${ }^{6} B$ ióloga, Doutora em Bioquímica Toxicológica, Professora, Universidade Federal da Fronteira Sul, Erechim, denicargnelutti@gmail.com.

\section{A R T I C L E}

Received: 14 July 2020

Accepted: 22 June 2021

Key words:

Drought

Medicinal plant

Oxidative stress

Biochemistry

Proline

\section{A B S T R A C T}

Climate change can cause imbalances in plants. Baccharis trimera is a specie usually found in harsh conditions and has medicinal and agricultural properties. Thus, this study aimed to evaluate the biochemical and physiological responses of this plant under water restriction (WR) levels. $B$. trimera samples were identified and collected in Erechim/RS and propagated in a greenhouse. When acclimated, they were subjected to $0,25,75$ and $100 \% \mathrm{WR}$, determined according to the water saturation in the soil by capillary action. After 30 days of treatment, the physiological responses: growth, and fresh and dry biomass; and the biochemical responses: activity of superoxide dismutase (SOD), guaiacol peroxidase (GP) and ascorbate peroxidase (APX) enzymes, proline, protein and hydrogen peroxide content, and lipid peroxidation, were determined. Data were submitted to regression analysis and Pearson correlation. The WR of $27.37 \%$, on average, induced an increase in physiological parameters, but the root growth was impaired in conditions above $50 \%$ of WR. With the increase in WR there was an increase in the activity of SOD in the shoot and APX in the root. In low WR conditions, proline contents were maintained. Therefore, with low levels of WR, around $27 \%$, B. trimera has increase in root growth and root and shoot biomass. Proline, and SOD and APX activity are a pathway that scavenging the stress generated by WR on $B$. trimera.

\section{R E S U M O}

Palavras-chave:

Estiagem

Planta medicinal

Estresse oxidativo

Bioquímica

Prolina
Alterações climáticas podem causar desequilíbrios nas plantas. Baccharis trimera é uma espécie frequentemente encontrada em condições adversas e apresenta propriedades medicinais e para uso na agricultura. Assim, objetivou-se avaliar as respostas bioquímicas e fisiológicas desta planta em níveis de restrição de água (RA). Amostras de $B$. trimera foram identificadas e coletadas em Erechim - RS e propagadas em casa de vegetação. Quando aclimatadas foram submetidas a 0, 25, 75 e $100 \%$ de RA, determinada de acordo com a saturação de água no solo por capilaridade. Após 30 dias de tratamento foram determinadas respostas fisiológicas: crescimento e biomassa fresca e seca; e respostas bioquímicas: atividade de enzimas superóxido dismutase (SOD), guaiacol peroxidase (GP) e ascorbato peroxidase (APX), conteúdo de prolina, proteína e peróxido de hidrogênio, e peroxidação de lipídeos. Os dados foram submetidos a análises de regressão e correlação de Pearson. A RA média de 27,37\% induziu aumento nos parâmetros fisiológicos avaliados, porém o crescimento das raízes foi prejudicado em condições de RA acima de $50 \%$. Com o aumento na RA houve o aumento na atividade das enzimas SOD na parte aérea e de APX na raiz. Em condição de baixa RA verificou-se a manutenção do conteúdo de prolina. Portanto, com baixos níveis de RA, em torno de $27 \%$, B. trimera tem aumento no crescimento de raiz e na biomassa da parte aérea e raiz. Prolina, SOD e APX são uma via de eliminação do estresse gerado pela RA em B. trimera.

\section{Revista Verde}

ISSN 1981-8203

Pombal, Paraiba, Brazil v. 16, i. 3, july.-sept, p.229-237, 2021

doi: $10.18378 /$ rvads.v16i3.8360 


\section{INTRODUCTION}

Plants are often exposed to environmental stresses, as drought, light excess, high and low temperatures, freezing, flooding, salinity, heavy metals, among others (BOWNE et al., 2018; LEUNG, 2018). These factors lead to biochemical and physiological imbalances in plants, causing reductions in productivity. Drought is one of the most worrying types of stress and can drastically decrease crop reproduction. Hydric stress in plants affects factors such as stomatal behaviour, reverse mobilization, enzymatic activity, leaf expansion, growth (FAROOQ et al., 2009) and can lead to oxidative stress (MITTLER, 2002) as a result of metabolic interruption due to cytoplasmic free water loss (SMIRNOFF, 1993).

Oxidative stress is characterized by accumulation of reduced and very reactive forms of molecular oxygen known as Reactive Oxygen Species (ROS), like singlet oxygen $\left({ }_{1} \mathrm{O}^{2}\right)$, superoxide radical $\left(\mathrm{O}^{2-}\right)$, hydrogen peroxide $\left(\mathrm{H}_{2} \mathrm{O}_{2}\right)$ and hydroxyl radical $(\mathrm{OH} \bullet)($ MITTLER, 2002; GILL; TUTEJA, 2010). The ROS accumulation can lead to lipid peroxidation causing intense damage to the plant attributed to lipid-derived radicals that further aggravate oxidative stress (GILL; TUTEJA, 2010). A consequence of water stress is also related to changes in secondary metabolites, which can be verified in the concentration of some essential oil compounds (RIOBA et al., 2015) or in monoterpenes concentration in medicinal plants under moderate drought conditions (NOWAK et al., 2010). The ROS scavenging pathways may be enzymatic, including the enzymes superoxide dismutase, ascorbate peroxidase, guaiacol peroxidase, glutathione S-transferase and catalase, or non-enzymatic, via ascorbate, $\alpha$-tocopherol, carotenoids, flavonoids and proline (GILL; TUTEJA, 2010).

Worldwide, including Brazil, the reduction in water availability has been worsened by climate change. Research has shown a tendency to increase temperatures and arid areas with water scarcity due to a decrease in the frequency of precipitation and prolonged droughts (AMBRIZZI et al., 2012). After 1990s there is an increasing in the minimal temperature allied with rate of warming more evident (AHMED et al., 2020). There is a relationship between the reduction of rainfall and the relative humidity with increasing temperatures for Brazilian conditions (SANCHEZ et al., 2017). The negative effects of the climatic situation, generated by anthropogenic actions that interact with natural processes in the environment, will cause changes in precipitation patterns that can provoke floods and droughts. Therefore, it is important to study the mechanisms by which plants develop to tolerate water restriction. A plant that is usually found in harsh conditions is the Baccharis trimera, popularly known in Brazil as "carqueja". This plant has high rustic growth habits, found in poor and acidic soils, preferring full sun conditions to grow (BONA, 2002).

B. trimera has been studied for its numerous medicinal properties, being commonly used for hepatic and gastric disorders treatment due to its antioxidant, anti-inflammatory and antimicrobial activity (RABELO; COSTA, 2018). In addition, it has applications in plant pathogenic bacteria control and phytoalexins induction in sorghum (MOURA et al., 2014) as a tool to reduce pesticides use. Thus, its uses in medicine and sustainable agriculture are in the process of being elucidated. However, the physiological and biochemical mechanisms by which $B$. trimera tolerates harsh environments still need to be unraveled. These studies are important in the sense of providing tools for breeding programs for cultivated plants tolerant to different types of stresses, and for seek strategies to species preservation (SOUZA, 2015). Besides that, it is known that the global changes tend to prolonged periods of drought, which makes it important to verify if this fact affects the quality of $B$. trimera and its benefits for use in medicine and agriculture, so that, if applicable, they must be appropriate adaptation strategies (BASU; SHAW, 2013). Elucidation of B. trimera biochemical and physiological responses can guarantee the adequacy of a better system, pursuing a higher active ingredients final yield by area and can providing tools for breeding programs for cultivated plants tolerant to hydric stress. Thus, physiological and biochemical changes in $B$. trimera plants submitted to different levels of water restriction were evaluated.

\section{MATERIALS AND METHODS}

This study was performed to analyze the responses of $B$. trimera to water restriction, which can be important for understanding, analyzing, and improving the defense strategies through various parameters. B. trimera sample were collected along BR 153 (Erechim, Brazil), at 27'37'41.07'S, $52^{\circ} 14^{\prime} 10.35^{\prime} \mathrm{W}$ geographical coordinates, according to the World Geodetic System (WGS-84). Phylogenetic classification of plant samples at species level was determined according to The Angiosperm Phylogeny Group system. Plant propagation occurred by $20 \mathrm{~cm}$ cuttings in pots containing Plantmax ${ }^{\circledR}$ substrate arranged in a greenhouse. The indole-3-butyric acid (1g $\mathrm{L}^{-1}$ ) was used as a rooting hormone by immersing the cuttings in solution for thirty seconds before being inserted into pots containing substrate. Irrigation occurred daily. During the period of execution of the tests, the total precipitation was $480 \mathrm{~mm}$, the average temperature was $19.26^{\circ} \mathrm{C}$ and average relative humidity was $74.49 \%$. After thirty days the cuttings with root development were then transplanted into new pots, two plants per pot, with 10 $\mathrm{cm}$ spacing between.

After acclimation period, plants were exposed to different levels of water deficit for thirty days in a greenhouse, to assess responses during the plant's growing season. Substrate waterhold capacity was determined in laboratory with using a precision scale and considering the water saturated soil mass that ascended by capillarity as Pot Capacity (PC) excluding the pot mass. From the total water mass retained by the substrate in PC, 25,50 and $75 \%$ were removed to determine the specific mass that the pots of each treatment should present. In order to know evapotranspiration water amount, pots without plants were weighed at two-day intervals. Water lost by evapotranspiration in the period was replaced by manual irrigation, respecting the water omission in each treatment $(25,50$ and $75 \%$ water deficit) and PC at $0 \%$ water deficit treatment (MAROSTICA et al., 2019).

B. trimera growth and biomass development were evaluated thirty days after treatment beginning. Growth $(\mathrm{GW})$ was determined by measuring root and shoot systems with a 
ruler. After harvesting, plants were immediately weighed on a precision scale in order to obtain the fresh biomass (FB). To determine the dry biomass (DB), plants were left at $70{ }^{\circ} \mathrm{C}$ until no mass variation.

Prior to biochemical analysis, shoot and root systems were macerated separately with liquid nitrogen until they become a homogeneous powder and then stored at $-80{ }^{\circ} \mathrm{C}$. After that, sample preparation occurred according to Zhu et al. (2004) followed by centrifugation at $14,000 \mathrm{~g}$ and $4{ }^{\circ} \mathrm{C}$ for $20 \mathrm{~min}$. Superoxide dismutase (SOD) activity was measured according to Giannopolitis and Ries (1997) adopting a lighting time of $15 \mathrm{~min}$. Guaiacol Peroxidase (GP) and Ascorbate Peroxidase (APX) activity were used to determine the antioxidant activity of hydrogen peroxide removal. Techniques were performed according to Zeraik et al., (2008) and $\mathrm{Zhu}$ et al., (2004), respectively. The Hydrogen peroxide $\left(\mathrm{H}_{2} \mathrm{O}_{2}\right)$ content in $B$. trimera was determined according to Loreto and Velikova (2001). The levels of lipid peroxidation products were estimated by the method described by El-Moshaty et al. (1993) measuring Malondialdehyde (MDA) concentration as the final product of lipid peroxidation by reaction with Thiobarbituric Acid (TBA). Protein concentration in $B$. trimera was measured by the Comassie Blue method according to Bradford (1976) using serum albumin as standard. In shoot samples, proline was measured by rapid colorimetric procedure described by Bates et al. (1973), based in the reaction between ninhydrin and amino acids.

The experiment was done as completely randomized design. Consisting of 3 replicates and 10 cuttings per replicate, in total 120 observations per water restriction (WR) assessed. Normality of residues were verified by Shapiro-Wilk test and homogeneity of variances by Barlett's test $(p \leq 0.05)$. Nonnormal data, GP and APX, were transformed by the square root. Once assumptions confirmed, data was submitted to analysis of variance with $\mathrm{F}$ test. Water restriction and systems (root and shoot) and the interaction between them were tested. Significant results equal or lower than 5\% probability level, were submitted to regression analysis with linear and quadratic models, the maximum and minimum point of curve were obtained by formula: $\mathrm{y}=-\mathrm{b} / 2 * \mathrm{c}$. Pearson's correlation coefficient was calculated $(p \leq 0.05)$. The analyses were performed at the statistical software RStudio (R CORE TEAM, 2020).

\section{RESULTS AND DISCUSSION}

We found a significant interaction between water restriction (WR) and the system (S) evaluated for absolute growth, SOD, APX and TBARS. Dry biomass show significant effect for water restriction. GP and fresh biomass showed significant difference to both, WR and the S. Protein and $\mathrm{H}_{2} \mathrm{O}_{2}$ just show difference in system evaluated. To proline contents, we verified significant effect of water restriction (Table 1).

Table 1. Summary of the Analysis of Variance for the dry biomass (DB), fresh biomass (FB), growth (GW), superoxide dismutase (SOD), guaiacol peroxidase (GP), ascorbate peroxidase (APX), thiobarbituric acid-reactive substances (TBARS), hydrogen peroxide $\left(\mathrm{H}_{2} \mathrm{O}_{2}\right)$, protein $(\mathrm{PTN})$ and proline $(\mathrm{PRL})$ in root and shoot systems of Baccharis trimera submitted of water restriction

\begin{tabular}{|c|c|c|c|c|c|c|c|c|c|c|}
\hline \multirow{2}{*}{ SV } & \multicolumn{10}{|c|}{$p$-value } \\
\hline & DB & FB & GW & SOD & GP & APX & TBARS & $\mathrm{H}_{2} \mathrm{O}_{2}$ & PTN & PRL \\
\hline $\begin{array}{l}\text { Water } \\
\text { restriction } \\
\text { (WR) }\end{array}$ & $0.0000^{*}$ & $0.0002^{*}$ & $0.0001^{*}$ & $5.9 \mathrm{E}-07^{*}$ & $0.0011^{*}$ & $0.1162^{\mathrm{ns}}$ & $0.1942^{\mathrm{ns}}$ & $0.1192^{\text {ns }}$ & $0.2828^{\text {ns }}$ & $3 \mathrm{E}-05^{*}$ \\
\hline $\begin{array}{l}\text { System } \\
\text { (S) }\end{array}$ & $0.0546^{\mathrm{ns}}$ & $0.0078^{*}$ & $0.0000^{*}$ & $7 \mathrm{E}-07^{*}$ & $0.0000^{*}$ & $0.0000^{*}$ & $0.0000^{*}$ & $0.0000^{*}$ & $0.0000^{*}$ & - \\
\hline $\begin{array}{c}\text { Interaction } \\
(\mathrm{WR} * \mathrm{~S})\end{array}$ & $0.2806^{\mathrm{ns}}$ & $0.748^{\mathrm{ns}}$ & $0.0074^{*}$ & $3.3 \mathrm{E}-06^{*}$ & $0.2780^{\mathrm{ns}}$ & $0.0006^{*}$ & $0.0029^{*}$ & $0.0967^{\text {ns }}$ & $0.0886^{\mathrm{ns}}$ & - \\
\hline $\begin{array}{l}\text { Linear } \\
\text { regression }\end{array}$ & $0.0019^{*}$ & $0.0063^{*}$ & $\begin{array}{l}\mathrm{r} 0.023^{*} \\
\mathrm{~s} 0.059^{\text {ns }}\end{array}$ & $\begin{array}{l}\mathrm{r} 0.000^{*} \\
\mathrm{~s} 0.708^{\mathrm{ns}}\end{array}$ & $0.9322^{\mathrm{ns}}$ & $0.0001^{*}$ & $0.0006^{*}$ & - & - & $0.0024^{*}$ \\
\hline $\begin{array}{l}\text { Quadratic } \\
\text { regression }\end{array}$ & $0.0032^{*}$ & $0.0068^{*}$ & $\begin{array}{l}\mathrm{r} 0.001^{*} \\
\mathrm{~s} 0.692^{\text {ns }}\end{array}$ & $\begin{array}{l}\mathrm{r} 0.001^{*} \\
\mathrm{~s} 0.004^{*}\end{array}$ & $0.0009^{*}$ & $0.5257^{\mathrm{ns}}$ & $0.0899^{\text {ns }}$ & - & - & $0.6731^{\mathrm{ns}}$ \\
\hline CV (\%) & 30.18 & 32.64 & 8.59 & 14.96 & 11.87 & 9.74 & 18.79 & 13.01 & 23.36 & 9.72 \\
\hline
\end{tabular}

We found that water restriction of $27.37 \%$, on average, induces an increase in physiological parameters. The dry biomass of $B$. trimera plants showed a significant statistical difference response to water deficit, but not to the system evaluated. The maximum point of DB was in $26.37 \%$ of water restriction. Shoot dry biomass development had been 1.9 times higher when compared to no water restriction (Figure 1A). The maximum point of FB (Figure 1B) was in $25.78 \% \mathrm{WR}$ and, of root growth (Figure 1C) was in 30\% WR. Therefore, these parameters show a tendency to increase with a little WR, followed by a decrease due to more restrictive conditions. Others results confirm higher shoot development when cocoa varieties ICS-9, and MA-15 were exposed to water deficit (SANTOS et al., 2014).

Data of the present study showed that in 30\% WR the root length development was 1.3 times higher than $0 \%$ WR (Figure 1C). Physiological data obtained in this study are in accordance with results reported by Price et al. (2002), observing root growth increase when Hedyosmum brasiliense were submitted to hydric deficiency. The observed root growth may be related to the increased exploitation of soil areas in search for water considering that the availability is higher in deeper horizons (PINHEIRO et al., 2005). However, the root growth of $B$. trimera is impaired in drought conditions above $50 \%$ of WR. 
Figure 1. Physiological parameters measured by dry biomass $\left(y=3.971+0.063 x-0.0012 x^{2} ; \quad R^{2}=0.341\right) \quad$ (A) fresh biomass. $\left(\mathrm{y}=8.614+0.139 \mathrm{x}-0.0027 \mathrm{x}^{2} ; \mathrm{R}^{2}=0.538\right) \quad(\mathrm{B})$ and growth (ROOT $\mathrm{y}=12.286+0.144 \mathrm{x}-0.0024 \mathrm{x}^{2} ; \mathrm{R}^{2}=0.882$; SHOOT $\mathrm{y}=$ not significant) (C) in root and shoot of Baccharis trimera plants exposed to water restriction.
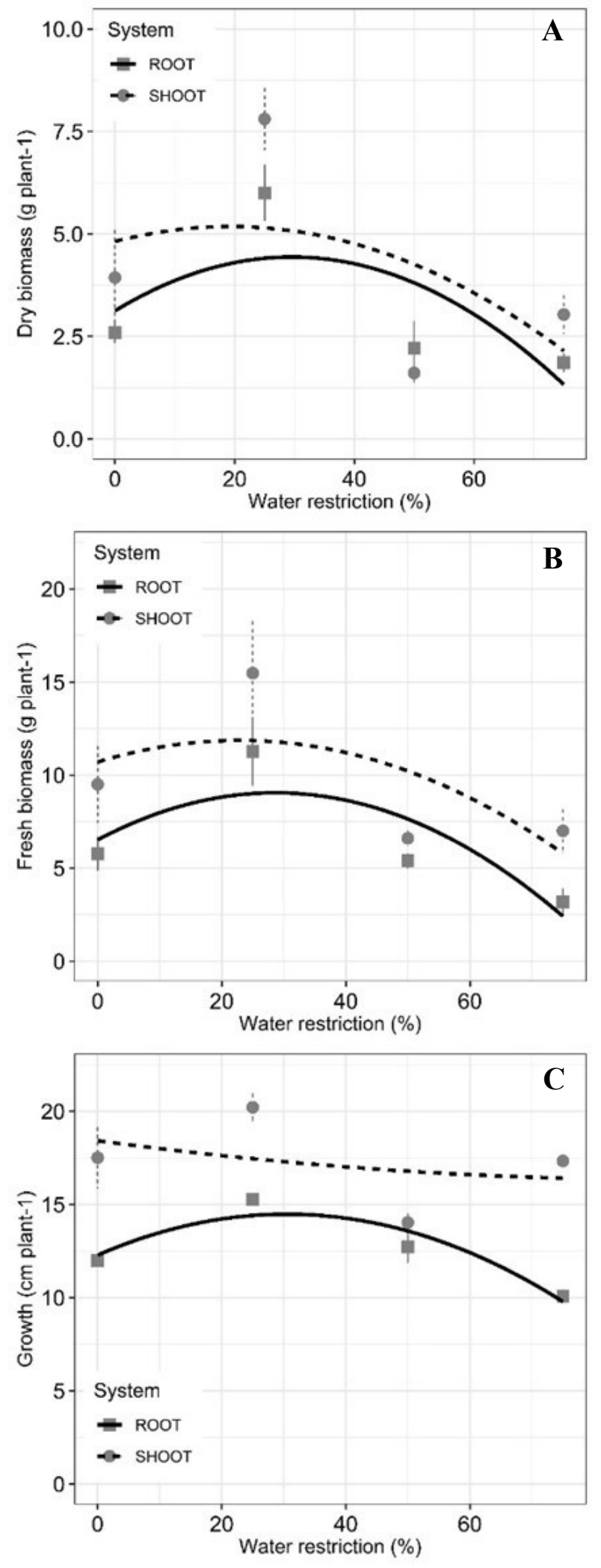

There are interaction between WR and system evaluated for SOD activity. Without restriction the enzymatic activity are higher in the roots (intercept for root $=4508.04$ and shoot $=$ 1925.18). The increase of WR caused decrease SOD activity in the roots and increased activity in the shoot. Under the conditions of highest WR tested, an inversion occurred, and the SOD activity in shoot become greater than that of the root. The minimum point of root SOD activity was in $70.26 \%$ WR and of shoot SOD activity was in $36.24 \%$ WR (Figure 2A). SOD constitutes the first line in plants defense being found in all cell compartments and activated under stress conditions (MITTLER, 2002). Generally, SOD activity increases when plants are exposed to water deficit (JALEEL et al., 2008; HAMEED et al., 2011; HOJATI et al., 2011). As it was verified in shoot of $B$. trimera.

Results that corroborate the analyses in B. trimera root was reported by Campos et al. (2011), according to the authors SOD and POD activity in Swingle Citrumelo was reduced during water deficit. This reduction of SOD activity may be a consequence of increase in proline contents, since pyrroline existent in proline molecules presents low capacity to provide electrons thus forming a charge transfer complex capable of sequestering free $\mathrm{O}_{2}$ and reduce superoxide ions production (REDDY et al., 2004). This may represent that B. trimera can tolerate a little water restriction, associated with proline activity and SOD activity balance. Even of drought stress effects, the application of proline can reduce and mitigate these effects, keeping productivity closer to normal water condition (GHAFFARI et al., 2019).

GP activity analyses in root and shoot systems from $B$. trimera shows a reduction in activity when exposed to milder WR, followed by an increase in activity for shoot in the most restrictive conditions (Figure 2B). The minimum point of GP was in $41.75 \% \mathrm{WR}$. The GP enzyme is related to lignin biosynthesis, and in the defense against biotic stress with $\mathrm{H}_{2} \mathrm{O}_{2}$ consumption (GILL; TUTEJA, 2010). The POD and APX enzyme are a ROS scavenging pathway, ROS fine tuning for signaling using $\mathrm{H}_{2} \mathrm{O}_{2}$ micro concentrations is the APX main biochemical role (MITTLER, 2002). APX showed no significant difference in shoot system, but for APX activity in root system it was found an increasing tendency when water availability was reduced (Figure $2 \mathrm{C})$. A negative correlations (-0.776 and -0.877$)$ in the root system was obtained with hydrogen peroxide and SOD activity, respectively (Table 2). The increase in $\mathrm{H}_{2} \mathrm{O}_{2}$ has a positive correlation with the increase in SOD activity on roots $(0.642)$, as it is a product of the activity of this enzyme (MITTLER, 2002). This is suggesting that SOD activity and hydrogen peroxide concentration in root was decreasing as APX activity increased.

Thiobarbituric Acid-Reactive Substances (TBARS) had interaction between WR and system evaluated. There was an increase in lipid peroxidation in the root and a decrease in the shoot, resulting from increased levels of WR (Figure 3A). The drought resistance can be measured by lipid peroxidation, through the content of the MDA that represents the degree of damage to the cell membrane (WANG et al., 2011). It's well known that lipid peroxidation is considered one of the worst plants damages and occurs when there is ROS accumulation (GILL; TUTEJA 2010). Petridis et al. (2012) reported in a study with olives that cultivars with greater drought resistance are those 
whose lipid peroxidation was lower. Biochemical parameters analyses between cultivated and wild plants allowed Ghorecha et al. (2014) to conclude that wild plants tolerance is related to lower MDA accumulation, and induction of SOD activation. The best yield in wheat plants according to Hameed et al. (2011) is related to ROS detoxification systems and decreased lipid peroxidation. There are a positive relation between TBARS and APX on root (0.776). But has a negative correlation between TBARS and SOD activity on root (-0.619). That can indicate APX activity on root in higher WT as being a more relevant pathway (Table 2).

Figure 2. Activity of antioxidant system enzymes such as superoxide dismutase (ROOT $y=4508-82.35 x+0.59 x^{2} ; R^{2}=0.931$, SHOOT $\left.y=1925-36,72 x+0,51 x^{2} ; R^{2}=0,964\right)(A)$, guaiacol peroxidase $\left(y=1.565-0,017 x+0,0002 x^{2} ; R^{2}=0,621\right)(B)$ and ascorbate peroxidase (ROOT $\mathrm{y}=0,735+0,0035 \mathrm{x} ; \mathrm{R}^{2}=0,981$, SHOOT $\mathrm{y}=$ not significant) $(\mathrm{C})$ in root and shoot of Baccharis trimera plants exposed to water restriction.
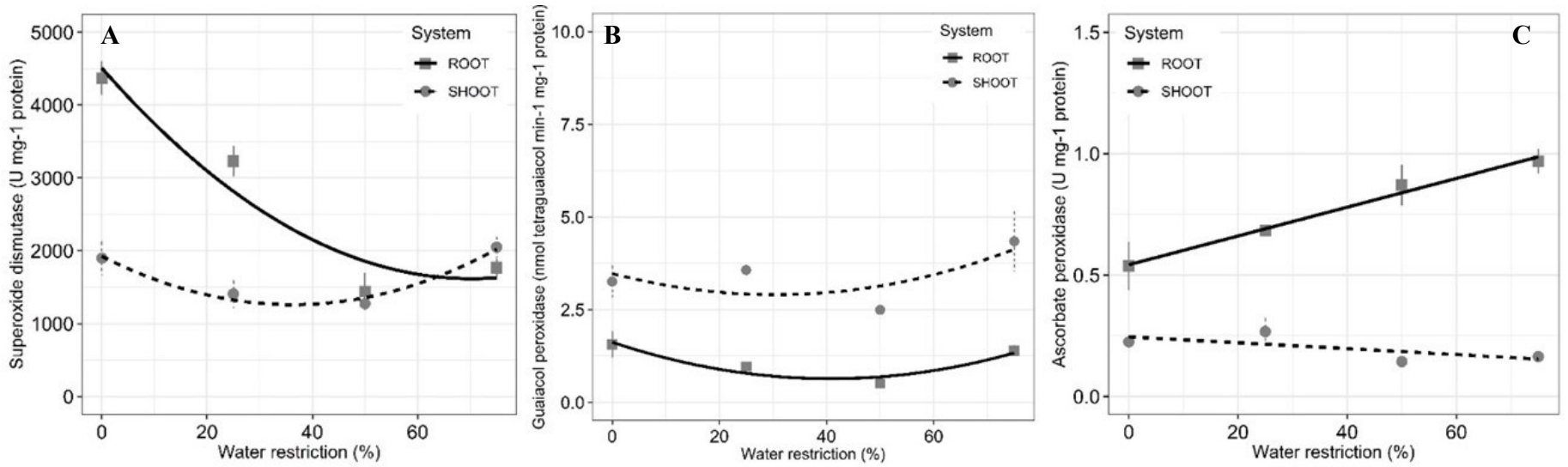

Table 2. Significant Pearson's correlation coefficients for the dry biomass (DB), fresh biomass (FB), growth (GW), superoxide dismutase (SOD), guaiacol peroxidase (GP), ascorbate peroxidase (APX), thiobarbituric acid-reactive substances (TBARS), hydrogen peroxide $\left(\mathrm{H}_{2} \mathrm{O}_{2}\right)$, protein (PTN) and proline (PRL) in root (r) and shoot (s) systems of Baccharis trimera submitted of water restriction

\begin{tabular}{cccccccccccccccc}
\hline $\begin{array}{c}\text { Respons } \\
\mathrm{e}\end{array}$ & $\mathrm{TBARSr}$ & $\mathrm{H}_{2} \mathrm{O}_{2} \mathrm{~S}$ & $\mathrm{H}_{2} \mathrm{O}_{2} \mathrm{r}$ & $\mathrm{PRLs}$ & $\mathrm{PTNr}$ & $\mathrm{SODs}$ & $\mathrm{SODr}$ & $\mathrm{GPr}$ & $\mathrm{GWs}$ & $\mathrm{GWr}$ & $\mathrm{FBs}$ & $\mathrm{FBr}$ & $\mathrm{DBs}$ & $\mathrm{DBr}$ \\
\hline $\mathrm{APXs}$ & - & 0.782 & - & 0.784 & - & - & 0.653 & - & 0.700 & - & 0.713 & 0.641 & 0.588 & - \\
$\mathrm{APXr}$ & 0.776 & - & -0.776 & - & -0.862 & - & -0.877 & - & - & - & - & - & - & - \\
$\mathrm{TBARSs}$ & - & - & - & 0.58 & - & - & - & - & - & - & - & - & - & - \\
$\mathrm{TBARSr}$ & - & - & - & - & -0.681 & - & -0.619 & - & - & -0.668 & -0.577 & -0.624 & -0.672 & -0.599 \\
$\mathrm{H}_{2} \mathrm{O}_{2} \mathrm{r}$ & - & - & - & - & 0.828 & - & 0.642 & - & - & - & - & - & - & - \\
$\mathrm{PRLs}$ & - & - & - & - & - & - & - & - & 0.819 & - & 0.754 & - & 0.782 & 0.662 \\
$\mathrm{PTNs}$ & - & - & - & - & - & -0.618 & - & - & - & - & - & - & - & - \\
$\mathrm{PTNr}$ & - & - & - & - & - & - & 0.831 & 0.593 & - & - & - & - & - & - \\
$\mathrm{SODs}$ & - & - & - & - & - & - & - & - & - & -0.611 & - & - & - & - \\
$\mathrm{GWs}$ & - & - & - & - & - & - & - & - & - & - & 0.833 & 0.652 & 0.831 & - \\
$\mathrm{GWr}$ & - & - & - & - & - & - & - & - & - & - & 0.676 & 0.853 & 0.628 & 0.780 \\
$\mathrm{FBs}$ & - & - & - & - & - & - & - & - & - & - & - & 0.943 & 0.728 & 0.643 \\
$\mathrm{FBr}$ & - & - & - & - & - & - & - & - & - & - & - & - & 0.685 & 0.733 \\
$\mathrm{DBs}$ & - & - & - & - & - & - & - & - & - & - & - & - & - & 0.883 \\
\hline
\end{tabular}

The content of hydrogen peroxide $\left(\mathrm{H}_{2} \mathrm{O}_{2}\right)$ and protein concentration were different between system evaluated, bigger in the shoot (Figure 3B and 3C). There is a positive correlation between both when evaluated at the root (0.828). Peroxide is an endogenous molecule involved in plants stress signaling. Increases in $\mathrm{H}_{2} \mathrm{O}_{2}$ concentration leads to a higher potential of hydroxyl radical $(\mathrm{OH} \bullet)$ production resulting in lipid peroxidation
(NEILL et al., 2002). When evaluating the water deficit effect on Catharanthus roseus metabolism, Jaleel et al. (2008) reported a reduction in $\mathrm{H}_{2} \mathrm{O}_{2}$ content, relating it to the effective activity of both the enzymatic and non-enzymatic antioxidant system. As well as $B$. trimera analyses, drought-resistant sugarcane cultivars studied by Boaretto et al. (2014) showed that with $70 \%$ water deficit there were no differences in $\mathrm{H}_{2} \mathrm{O}_{2}$ content, only a 
difference occurring for susceptible cultivar and under severe stress. In Jatropha curcas (L.) plants, Moura et al. (2016) reported that less significant losses caused by water deficit are associated with a lower reduction in protein content. The maintenance of these variables may indicate the ability of $B$. trimera to tolerate the stress caused by WR.

Figure 3. Levels of lipid peroxidation products measured by thiobarbituric acid-reactive substances (ROOT $y=7.183+0.051$; $\mathrm{R}^{2}=0.821$, SHOOT $\mathrm{y}=$ not significant) (A), hydrogen peroxide contents ( $\mathrm{y}=$ not significant) (B) and concentration of protein $(\mathrm{y}=\mathrm{not}$ significant) (C) in root and shoot of Baccharis trimera plants exposed to water restriction
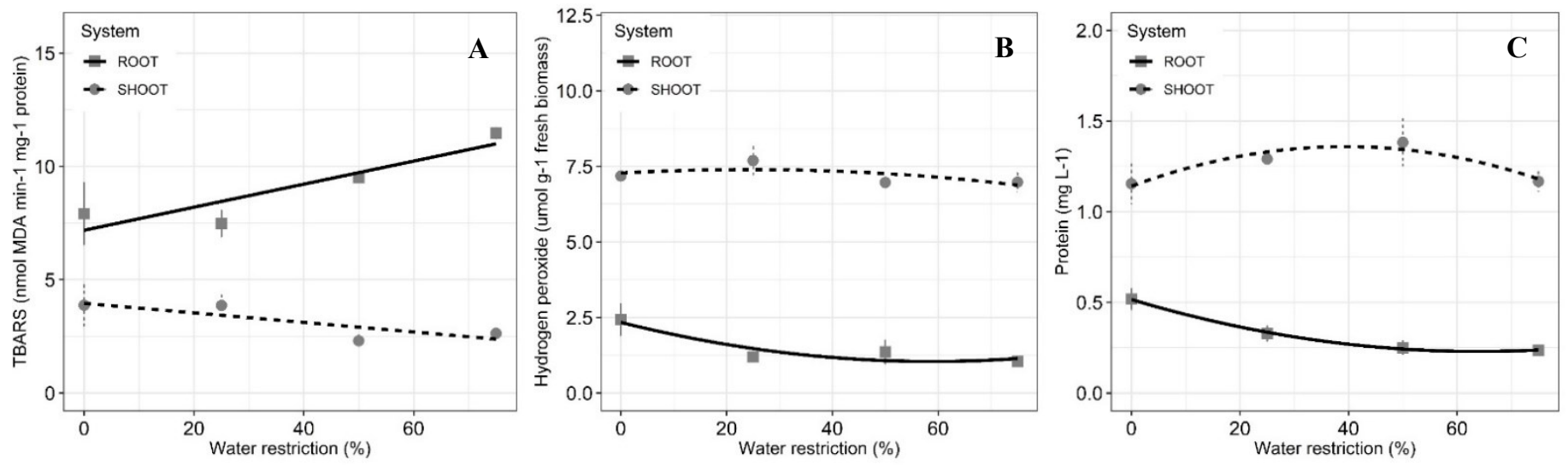

Water restriction levels significantly influence proline content in shoot. Condition of low water restriction maintains the content of this amino acid. We found a slight increase in response to few WR. In the conditions of higher WR, proline content tends to drop. The minimum point was observed in $66.5 \%$ of WR (Figure 4). Proline is one of the amino acids most commonly associated with responses to water stress (CHEN; KAO, 1993). Proline synthesis has been related to a mechanism for cytoplasmic acidosis relief and maintenance of NADPH at compatible values with metabolism (GILL; TUTEJA, 2010). In addition, free proline acts as an osmoprotectant, protein stabilizer, metal chelator, lipid peroxidation inhibitor, and $\mathrm{OH} \bullet$ and ${ }_{1} \mathrm{O}^{2}$ eliminator (VALLIYODAN; NGUYEN, 2006). Corroborating our study, citrumelo swingle transgenic plants containing a gene encoding the key enzyme for proline biosynthesis showed 2.5 times higher proline content under moderate water stress (CAMPOS et al., 2011). Primary nitrogen metabolism modulation by water deficit through dependent and independent abscisic acid (ABA), in Medicago truncatula demonstrated that water deficit induced $\mathrm{ABA}$ accumulation, consequently inducing asparagine and proline accumulation, such osmolite increase contributed to the osmotic adjustment (PLANCHET et al., 2011).

In $B$. trimera the higher proline content $(13.21 \mu \mathrm{mol}$ of proline $\mathrm{g}^{-1}$ of plant tissue) obtained under $25 \%$ water restriction may have led to osmotic adjustment, which was possibly responsible for the 1.3 times increase in root and shoot length, and 1.9 times in fresh biomass. Under conditions of abiotic stress, the transcription of genes related to proline content is increased in tolerant genotypes (BENITEZ et al., 2016). This demonstrates that the overcoming abiotic stress mediated by proline is an interesting route for breeding programs. Proline has a positive correlation with APX and TBARS on shoot $(0.784$ and 0.580 respectively), and a positive correlation with GW (0.819) and FB (0.754) shoot and DB root (0.782) and shoot (0.662). It can indicated proline as being relevant for maintaining high physiological parameters in WR conditions up to $30 \%$ (Table 2).

Figure 4. Proline content in Baccharis trimera plants exposed to water restriction $\left(y=10.491-0.027 x-0.0002 x^{2} ; R^{2}=0.157\right)$.

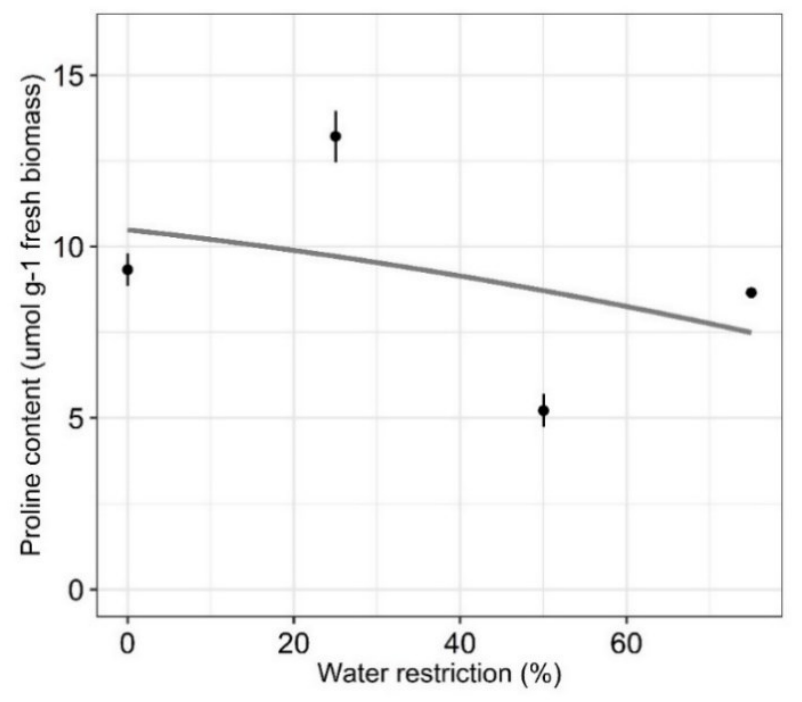

In B. trimera low water restriction, $27.37 \%$ on average, increase growth, dry biomass and fresh biomass, limited until drought conditions above $50 \%$ of WR. B. trimera can tolerate a little water restriction, related with proline activity associated, in milder conditions, with SOD activity in the roots. In conditions of higher restriction can be related with APX in the root and SOD in the shoot. Therefore, B. trimera maintains root growth and root and shoot biomass under low WR levels. Proline, and APX and SOD activity can be a pathway that scavenging the stress generated by WR and maintains biomass and growth (Figure 5). 
Figure 5. Summary of physiological responses measured by dry biomass (DB), fresh biomass (FB) and growth (GW) and biochemical responses measured by superoxide dismutase (SOD), guaiacol peroxidase (GP), ascorbate peroxidase (APX), thiobarbituric acid-reactive substances (TBARS), hydrogen peroxide $\left(\mathrm{H}_{2} \mathrm{O}_{2}\right)$, protein $(\mathrm{PTN})$ and proline (PRL) in root and shoot systems of Baccharis trimera submitted of water restriction.

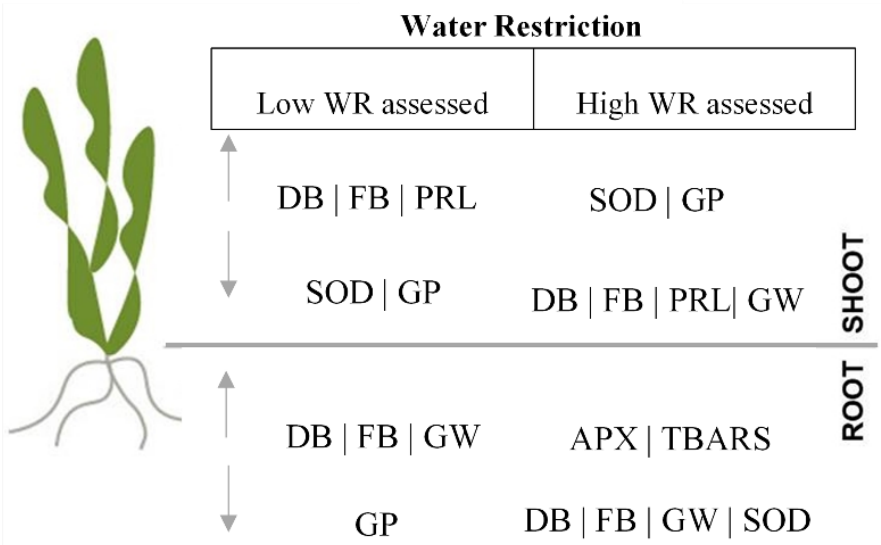

\section{CONCLUSION}

B. trimera maintains root growth and root and shoot biomass under low WR levels. The proline and the APX and SOD activity can be a pathway that scavenging the stress generated by WR on B. trimera. This pathways can be an important tool to be considered in breeding programs to enhance drought tolerance in plants and for seek strategies to medicinal species cultivation in harsh conditions. In addition, this study provides a way to optimize the sustainable production of these species, in view of a greater biomass production.

\section{ACKNOWLEDGEMENTS}

The authors wish to thank the Conselho Nacional de Desenvolvimento Científico e Tecnológico (CNPq) and Fundação de Amparo à Pesquisa do Estado do Rio Grande do Sul (FAPERGS).

\section{REFERENCES}

AHMED, N.; WANG, G.; OLUWAFEMI, A.; MUNIR, S.; HU, Z. Y.; SHAKOOR, A.; IMRAN, M. A. Temperature trends and elevation dependent warming during 1965-2014 in headwaters of Yangtze River, Qinghai Tibetan Plateau. Journal of Mountain Science, 17:556-571, 2020. 10.1007/s11629-019-5438-3

AMBRIZZI, T.; ARAÚJO, M. Sumário Executivo do Volume 1 - Base Científica das Mudanças Climáticas. Contribuição do Grupo de Trabalho 1 para o $1^{\circ}$ Relatório de Avaliação Nacional do Painel Brasileiro de Mudanças Climáticas. PBMC, Rio de Janeiro, 2012.
BASU, M.; SHAW, R. Water policy, climate change and adaptation in South Asia. International Journal of Environmental Studies, 70:175-191, 2013. 10.1080/00207233.2013.781736

BATES, L. S.; WALDREN, R. P.; TEARE, I. D. Rapid determination of free proline for water-stress studies. Plant and Soil, 39:205-207, 1973. 10.1007/BF00018060

BENITEZ, L. C.; VIGHI, I. L.; AULER, P. A.; AMARAL, M. N.; MORAES, G. P.; RODRIGUES, G. S.; MAIA, L. C.; MAGALHÃES JUNIOR, A. M; BRAGA, E. J. B. Correlation of proline content and gene expression involved in the metabolism of this amino acid under abiotic stress. Acta Physiologiae Plantarum, 38(267):1-12, 2016. 10.1007/s11738-016-2291-7

BOARETTO, L. F.; CARVALHO, G.; BORGO, L.; CRESTE, S.; LANDELL, M. G.; MAZZAFERA, P.; AZEVEDO, R. A. Water stress reveals differential antioxidant responses of tolerant and non-tolerant sugarcane genotypes. Plant Physiology and Biochemistry, 74:165-175, 2014. 10.1016/j.plaphy.2013.11.016

BONA, C. M. Estaquia, calagem e sombreamento de carqueja. Dissertation, Federal University of Paraná, Curitiba, 2002, 81p.

BOWNE, J.; BACIC, A.; TESTER, M.; ROESSNER, U. Abiotic Stress and Metabolomics. Annual Plant Reviews, 43:61-85, 2018. 10.1002/9781119312994.apr0463

BRADFORD, M. A rapid and sensitive method for the quantification of microgram quantities of protein utilizing the principle of protein-dye binding. Analytical Biochemistry, 72(12):248-254, 1976. 10.1016/0003-2697(76)90527-3

CAMPOS, M. K. F.; CARVALHO, K.; SOUZA, F. S.; MARUR, C. J.; PEREIRA, L. F. P.; BESPALKOK-FILHO, J. C.; VIEIRA, L. G. E. Drought tolerance and antioxidant enzymatic activity in transgenic 'Swingle' citrumelo plants over-accumulating proline. Environmental and Experimental Botany, 72(2):242250, 2011. 10.1016/j.envexpbot.2011.03.009

CHEN, C. T.; KAO, C. H. Osmotic stress and water stress have opposite effects on putrescine and proline production in excised rice leaves. Plant Growth Regulation, 13:197-202, 1993.

EL-MOSHATY, F. I. B.; PIKE, S. M.; NOVACKY, A. J.; SEHGAL, O. P. Lipid peroxidation and superoxide production in cowpea (Vigna unguiculata) leaves infected with tobacco ringspot virus or southern bean mosaic virus. Physiological Molecular Plant Pathology 43(2):109-119, 1993. 10.1006/pmpp.1993.1044

FAROOQ, M.; WAHID, A.; KOBAYASHI, N.; FUJITA, D.; BASRA, S. M. A. Plant drought stress: effects, mechanisms and management. Agronomy for Sustainable Development, 29:185212, 2009.10.1051/agro:2008021

GHAFFARI, H.; TADAYON, M. R.; NADEEM, M.; CHEEMA, M.; RAZMJOO, J. Proline-mediated changes in antioxidant enzymatic activities and the physiology of sugar beet under 
drought stress. Acta Physiologiae Plantarum, 41(23):1-13, 2019. $10.1007 / \mathrm{s} 11738-019-2815-\mathrm{z}$

GHORECHA, V.; PATEL, K.; INGLE, S.; SUNKAR, R.; KRISHNAYYA, N. S. R. Analysis of biochemical variations and microRNA expression in wild (Ipomoea campanulata) and cultivated (Jacquemontia pentantha) species exposed to in vivo water stress. Physiology and Molecular Biology of Plants, 20(1):57-67, 2014. 10.1007/s12298-013-0207-1

GIANNOPOLITIS, C. N.; RIES, S. K. Purification and quantitative relationship with water-soluble protein in seedlings. Plant Physiology, 59(2):315-318, 1997. 10.1104/pp.59.2.315

GILL, S. S.; TUTEJA, N. Reactive oxygen species and antioxidant machinery in abiotic stress tolerance in crop plants. Plant Physiology and Biochemistry, 48(12):909-930, 2010. 10.1016/j.plaphy.2010.08.016

HAMEED, A.; BIBI, N.; AKHTER, J.; IQBAL, N. Differential changes in antioxidants, proteases, and lipid peroxidation in flag leaves of wheat genotypes under different levels of water deficit conditions. Plant Physiology and Biochemistry, 49(2):178-185, 2011. 10.1016/j.plaphy.2010.11.009

HOJATI, M.; MODARRES-SANAVY, A. S. M.; KARIMI, M.; GHANATI, F. Responses of growth and antioxidant systems in Carthamus tinctorius L. under water deficit stress. Acta Physiologiae Plantarum, 33:105-112, 2011. 10.1007/s11738010-0521-y

JALEEL, C. A.; SANKAR, B.; MURALI, P. V.; GOMATHINAYAGAM, M.; LAKSHMANAN, G. M.; PANNEERSELVAM, R. Water deficit stress effects on reactive oxygen metabolism in Catharanthus roseus: impacts on ajmalicine accumulation. Colloids and Surfaces Biointerfaces, 62(1):105-111, 2008. 10.1016/j.colsurfb.2007.09.026

LORETO, F.; VELIKOVA, V. Isoprene produced by leaves protects the photosynthetic apparatus against ozone damage, quenches ozone products, and reduces lipid peroxidation of cellular membranes. Plant Physiology, 127(4):1781-1787, 2001. 10.1104/pp.010497

LEUNG, D. W. M. Studies of Catalase in Plants Under Abiotic Stress. Antioxidants and Antioxidant Enzymes in Higher Plants. In: GUPTA D., PALMA J., CORPAS F. (eds) Antioxidants and Antioxidant Enzymes in Higher Plants. Springer, Cham. 1(1):2739, 2018. 10.1007/978-3-319-75088-0_2

MAROSTICA, T. F.; CAZAROLLI, L. H.; MOURA, G. S.; LUZ, V. C. D.; GUIMARÃES, E. A. C. M.; CARGNELUTTI, D. Does Allium sativum L. tolerate water déficit? Scientific Electronic Archives, 12(6):13-51, 2019. 10.36560/1262019963

MITTLER, R. Oxidative stress, antioxidants and stress tolerance. Trends in Plant Science, 7(9):405-410, 2002. 10.1016/S13601385(02)02312-9
MOURA, A. R.; NOGUEIRA, R. J. M. C.; SILVA, J. A. A.; LIMA, T. V. Relações hídricas e solutos orgânicos em plantas jovens de Jatropha curcas L. sob diferentes regimes hídricos. Ciência Florestal, 26(2):345-354, 2016. $10.5902 / 1980509822735$

MOURA, G. S.; FRANZENER, G.; STANGARLIN, J. R.; SCHWAN-STRADA, K. R. F. Atividade antimicrobiana e indutora de fitoalexinas do hidrolato de carqueja [Baccharis trimera (Less.) DC.]. Revista Brasileira de Plantas Medicinais, 16(2):309-315, 2014. 10.1590/1983-084X/10_121

NEILL, S. J.; DESIKAN, R.; CLARKE, A.; HURST, R. D.; HANCOCK, J. T. Hydrogen peroxide and nitric oxide as signaling molecules in plants. Journal of Experimental Botany, 53(372)1237-1247, 2002. 10.1093/jexbot/53.372.1237

NOWAK, M.; KLEINWÄCHTER, M.; MANDERSCHEID, R.; WEIGEL, H. J.; SELMAR, D. Drought stress increases the accumulation of monoterpenes in sage (Salvia officinalis) an effect that is compensated by elevated carbon dioxide concentration. Journal of Applied Botany and Food Quality, 83(2):133-136, 2010.

PETRIDIS, A.; THERIOS, I.; SAMOURIS, G.; KOUNDOURAS, S.; GIANNAKOULA, A. Effect of water deficit on leaf phenolic composition, gas exchange, oxidative damage and antioxidant activity of four Greek olive (Olea europaea L.) cultivars. Plant Physiology and Biochemistry, 60(1):1-11, 2012. 10.1016/j.plaphy.2012.07.014

PINHEIRO, H. A.; DA MATTA, F. M.; CHAVES, A. R. M.; LOUREIRO, M. E.; DUCATTI, C. Drought tolerance is associated with rooting depth and stomatal control of water use in clones of Coffea canephora. Annals of Botany, 96(1):101-108, 2005. 10.1093/aob/mci154

PLANCHET, E.; RANNOU, O.; RICOULT, C.; BOUTETMERCEY, S.; MAIA-GRONDARD, A.; LIMAMI, A. M. Nitrogen metabolism responses to water deficit act through both abscisic acid (ABA)-dependent and independent pathways in Medicago truncatula during post-germination. Journal of Experimental Botany, 62(1):605-615, 2011. 10.1093/jxb/erq294

PRICE, A. H.; STEELE, K. A.; GORHAM, J.; BRIDGES, J. M.; MOORE, B. J.; EVANS, J. L.; RICHARDSON, P.; JONES, R. G. W. Upland rice grown in soil-filled chambers and exposed to contrasting water-deficit regimes: I. Root distribution, water use and plant water status. Field Crop Research, 76(1):11-24, 2002. 10.1016/S0378-4290(02)00012-6

R Core Team. R: A language and environment for statistical computing. R Foundation for Statistical Computing, 2020. https://www.R-project.org/.

RABELO, A. C. S.; COSTA, D. C. A review of biological and pharmacological activities of Baccharis trimera. ChemicoBiological Interactions, 296:65-75, 2018. 10.1016/j.cbi.2018.09.002 
REDDY, A. R.; CHAITANYA, K. V.; VIVEKANANDAN, M. Drought-induced responses of photosynthesis and antioxidant metabolism in higher plants. Journal of Plant Physiology, 161(11):1189-1202, 2004. 10.1016/j.jplph.2004.01.013

RIOBA, N. B.; ITULYA, F. M.; SAIDI, M.; DUDAI, N.; BERNSTEIN, N. Effects of nitrogen, phosphorus and irrigation frequency on essential oil content and composition of sage (Salvia officinalis L.). Journal of Applied Research on Medicinal and Aromatic Plants, 2(1):21-29, 2015. 10.1016/j.jarmap.2015.01.003

SANCHEZ, F. O.; SILVA, R. V.; FERREIRA, R. V.; CAMPOS, C. A. A. Climate change in the Triângulo Mineiro region Brazil. Revista Brasileira de Climatologia, 21(21):570-587, 2017. 10.5380/abclima.v21i0.51867

SANTOS, I. C.; ALMEIDA, A. A. F.; ANHERT, D.; CONCEIÇÃO, A. S.; PIROVANI, C. P.; PIRES, J. L.; VALLE, R. R.; BALIGAR, V. C. Molecular, physiological and biochemical responses of Theobroma cacao L. genotypes to soil water deficit. PLoS One, 9(12), 2014. 10.1371/journal.pone.0115746

SMIRNOFF, N. The role of active oxygen in the response of plants to water deficit and desiccation. New Phytologist, 125:2758, 1993. 10.1111/j.1469-8137.1993.tb03863.x

SOUZA, D. C. L. Técnicas moleculares para caracterização e conservação de plantas medicinais e aromáticas: uma revisão. Revista Brasileira de Plantas Medicinais, 17(3):495-503, 2015. 10.1590/1983-084X/13_071

VALLIYODAN, B.; NGUYEN, H. T. Understanding regulatory networks and engineering for enhanced drought tolerance in plants. Current opinion in plant biology, 9(2):189-195, 2006. 10.1016/j.pbi.2006.01.019

WANG, Y.; SUO, B.; ZHAO, T.; QU, X.; YUAN, L.; ZHAO, $\mathrm{X}$; ZHAO, H. Effect of nitric oxide treatment on antioxidant responses and psbA gene expression in two wheat cultivars during grain filling stage under drought stress and rewatering. Acta Physiologiae Plantarum, 33:1923-1932, 2011. 10.1007/s11738-011-0740-X

ZERAIK, A. E.; SOUZA, F. S.; FATIBELLO-FILHO, O. Desenvolvimento de um spot test para o monitoramento da atividade da peroxidase em um procedimento de purificação. Química Nova, 31(4):731-734, 2008. 10.1590/S010040422008000400003

ZHU, Z.; WEI, G.; LI, J.; QIAN, Q.; YU, J. Silicon alleviates salt stress and increases antioxidant enzymes activity in leaves of salt-stressed cucumber (Cucumis sativus L.). Plant Science, 167(3):527-533, 2004. 10.1016/j.plantsci.2004.04.020 